The University of Maine

DigitalCommons@UMaine

Earth Science Faculty Scholarship

Earth Sciences

$10-1-2003$

\title{
Prismatine and Ferrohogbomite-2N2S in Granulite-Facies Fe-Oxide Lenses in the Eastern Ghats Belt at Venugopalapuram, Vizianagaram District, Andhra Pradesh, India: Do Such Lenses Have a Tourmaline-Enriched Lateritic Precursor?
}

Edward S. Grew

University of Maine - Main, esgrew@maine.edu

A. T. Rao

K.K.V.S. Raju

C. Hejny

J. M. Moore

See next page for additional authors

Follow this and additional works at: https://digitalcommons.library.umaine.edu/ers_facpub Part of the Earth Sciences Commons

\section{Repository Citation}

Grew, Edward S.; Rao, A. T.; Raju, K.K. V.S.; Hejny, C.; Moore, J. M.; Waters, D. J.; Yates, Martin G.; and Shearer, C. K., "Prismatine and Ferrohogbomite-2N2S in Granulite-Facies Fe-Oxide Lenses in the Eastern Ghats Belt at Venugopalapuram, Vizianagaram District, Andhra Pradesh, India: Do Such Lenses Have a Tourmaline-Enriched Lateritic Precursor?" (2003). Earth Science Faculty Scholarship. 71 .

https://digitalcommons.library.umaine.edu/ers_facpub/71

This Article is brought to you for free and open access by DigitalCommons@UMaine. It has been accepted for inclusion in Earth Science Faculty Scholarship by an authorized administrator of DigitalCommons@UMaine. For more information, please contact 
Authors

Edward S. Grew, A. T. Rao, K.K. V.S. Raju, C. Hejny, J. M. Moore, D. J. Waters, Martin G. Yates, and C. K. Shearer 


\title{
Prismatine and ferrohögbomite-2N2S in granulite-facies
} Fe-oxide lenses in the Eastern Ghats Belt at Venugopalapuram, Vizianagaram district, Andhra Pradesh, India: do such lenses have a tourmaline-enriched lateritic precursor?

\author{
E. S. Grew ${ }^{1} *$, A. T. RaO ${ }^{2}$, K. K. V. S. Raju ${ }^{2}$, C. Hejny ${ }^{3}$, J. M. Moore ${ }^{4}$, D. J. Waters ${ }^{5}$, M. G. Yates ${ }^{1}$ and \\ C. K. SHEARER ${ }^{6}$ \\ ${ }^{1}$ Department of Earth Sciences, University of Maine, 5790 Bryand Center, Orono, Maine 04469, USA \\ 2 Department of Geology, Andhra University, Visakhapatnam 530 003, India \\ ${ }^{3}$ School of Physics, University of Edinburgh, The King's Buildings, Edinburgh EH9 3JZ, UK \\ ${ }^{4}$ Department of Exploration Geology, Rhodes University, P O Box 94, Grahamstown, 6140 South Africa \\ ${ }^{5}$ Department of Earth Sciences, Oxford University, Parks Road, Oxford OX1 3PR, UK \\ ${ }^{6}$ Institute of Meteoritics, University of New Mexico, Albuquerque, New Mexico 87131, USA
}

\section{ABSTRACT}

Fluorine-rich prismatine, $(\square, \mathrm{Fe}, \mathrm{Mg})(\mathrm{Mg}, \mathrm{Al}, \mathrm{Fe})_{5} \mathrm{Al}_{4}(\mathrm{Si}, \mathrm{B}, \mathrm{Al})_{5} \mathrm{O}_{21}(\mathrm{OH}, \mathrm{F})$, with $\mathrm{F} /(\mathrm{OH}+\mathrm{F})=0.36-0.40$ and hercynite are major constituents of a Fe-Al-B-rich lens in ultrahigh-temperature granulite-facies quartz-sillimanite-hypersthene-cordierite gneisses of the Eastern Ghats belt, Andhra Pradesh, India. Hemo-ilmenite, sapphirine, magnetite, biotite and sillimanite are subordinate. Lithium, $\mathrm{Be}$ and $\mathrm{B}$ are concentrated in prismatine (140 ppm Li, $170 \mathrm{ppm} \mathrm{Be}$, and 2.8-3.0 wt.\% $\left.\mathrm{B}_{2} \mathrm{O}_{3}\right)$. Another Fe-rich lens is dominantly magnetite, which encloses fine-grained zincian ferrohögbomite- $2 N 2 S$, $\left(\mathrm{Fe}^{2+}, \mathrm{Mg}, \mathrm{Zn}, \mathrm{Al}\right)_{6}$ $\left(\mathrm{Al}, \mathrm{Fe}^{3+}, \mathrm{Ti}\right)_{16} \mathrm{O}_{30}(\mathrm{OH})_{2}$, containing minor $\mathrm{Ga}_{2} \mathrm{O}_{3}$ (0.30-0.92 wt.\%). Fe-Al-B-rich lenses with prismatine (or kornerupine) constitute a distinctive type of B-enrichment in granulite-facies rocks and have been reported from four other localities worldwide. A scenario involving a tourmalineenriched lateritic precursor affected by dehydration melting is our preferred explanation for the origin of the Fe-Al-B-rich lenses at the five localities. Whole-rock analyses and field relationships at another of these localities, Bok se Puts, Namaqualand, South Africa, are consistent with this scenario. Under granulite-facies conditions, tourmaline would have broken down to give kornerupine-prismatine ( \pm other borosilicates) plus a sodic melt containing $\mathrm{H}_{2} \mathrm{O}$ and $\mathrm{B}$. Removal of this melt depleted the rock in $\mathrm{Na}$ and $\mathrm{B}$, but the formation of ferromagnesian borosilicate phases in the restite prevented total loss of $\mathrm{B}$.

KEYwORDs: prismatine, ferrohögbomite, Eastern Ghats Belt, India, Namaqualand, South Africa.

\section{Introduction}

ELEVATED concentrations of the light lithophile trace elements $\mathrm{Li}, \mathrm{Be}$ and $\mathrm{B}$ are not common in granulite-facies rocks. For this reason the report by Ramesh Kumar et al. (1995) of relatively abundant $\mathrm{B}$ - and Ga-bearing surinamite, $(\mathrm{Mg}, \mathrm{Fe})_{3}(\mathrm{Al}, \mathrm{Fe})_{3} \mathrm{O}\left[\mathrm{AlBeSi}_{3} \mathrm{O}_{15}\right]$, in cordieritesillimanite gneisses from several localities in the

*E-mail: esgrew@maine.edu

DOI: $10.1180 / 0026461036750144$
Vizianagaram (Vijayanagaram) district, an area in the Eastern Ghats Belt, attracted our interest. However, our study of samples from this area, including several examined by Ramesh Kumar et al. (1995), did not turn up surinamite, but abundant hypersthene instead, and thus the B-Be-Ga enrichment reported by Ramesh Kumar et al. (1995) could not be confirmed (Grew et al., 2001). Associated with the quartz-sillimanitehypersthene-cordierite gneisses are lenses rich in oxide, one of which contained abundant prismatine, the B-dominant member of the kornerupine 
series (Grew et al., 1996), while another contained a högbomite-group mineral in minor amounts. This particular prismatine contains minor $\mathrm{Be}$, and högbomite, minor $\mathrm{Ga}$, so that the trace elements reported by Ramesh Kumar et al. (1995) are found in the Eastern Ghats Belt, although not in the proportions and concentrations reported by those authors.

Prismatine is the B-dominant member of the kornerupine-prismatine series, ( $\square, \mathrm{Fe}, \mathrm{Mg})$ $(\mathrm{Mg}, \mathrm{Al}, \mathrm{Fe})_{5} \mathrm{Al}_{4}(\mathrm{Si}, \mathrm{B}, \mathrm{Al})_{5} \mathrm{O}_{21}(\mathrm{OH}, \mathrm{F})$, which has been reported from about 70 localities worldwide, with rare exceptions in Precambrian upper amphibolite- and granulite-facies metamorphic complexes (Grew, 2002a), including Paderu and Kondapalli in the Eastern Ghats belt (e.g. Higgins et al., 1979; Grew, 1982; Nanda et al., 1983; Grew et al., 1990a). Prismatine and kornerupine have commonly formed from the prograde breakdown of tourmaline or in anatectic melts, but B metasomatism has played a role in some cases (Grew, 2002a). This series is most commonly found in silica-undersaturated, relatively aluminous and magnesian rocks, but members richer in B can occur in a greater diversity of chemical environments, including the iron oxide-rich rocks described in the present paper.

Ferrohögbomite-2N2S, $\left(\mathrm{Fe}^{2+}, \mathrm{Mg}, \mathrm{Zn}, \mathrm{Al}\right)_{6}$ $\left(\mathrm{Al}, \mathrm{Fe}^{3+}, \mathrm{Ti}\right)_{16} \mathrm{O}_{30}(\mathrm{OH})_{2}$, is an $\mathrm{Fe}$-dominant polysome of the polysomatic högbomite group (Armbruster, 2002; Hejny et al. 2002). Högbomite-group minerals are found rather widely, though sparsely, in a variety of environments, notably iron deposits, sulphide deposits and in medium- to high-grade metamorphic rocks (e.g. Petersen et al., 1989; Grew et al., 1990b), including Kantakapalli in the Eastern Ghats (Rao et al., 1997). In many cases, högbomite-group minerals did not crystallize at high temperature, but instead formed by breakdown or reaction of $\mathrm{Fe}-\mathrm{Mg}$-Al-Ti oxides during retrogression under hydrating or oxidizing conditions.

In the present paper, we describe in detail the newly found prismatine and ferrohögbomite- $2 N 2 S$ and outline a scenario for prismatine formation from granulite-facies metamorphism of a tourmaline-enriched lateritic precursor.

\section{Samples}

The two samples are from Venugopalapuram $\left(18^{\circ} 09^{\prime} 30^{\prime \prime} \mathrm{N}, 83^{\circ} 26^{\prime} 40^{\prime \prime} \mathrm{E}\right)$, a few kilometres north of Vizianagaram town. One sample (\#15) is a prismatine-oxide lens in quartz-sillimanite- hypersthene-cordierite gneiss. In hand specimen the rock is black and appears to be opaque, but in thin section it has a cellular structure consisting of subparallel prisms up to several $\mathrm{mm}$ long of prismatine partly enclosed in oxides (Fig. 1). Prismatine is transparent and is pleochroic from very pale yellow to pale grey-blue. Abundant hercynite is riddled with blebs and lamellae of exsolved magnetite except in narrow margins around larger grains of magnetite (Fig. 2) and hematite-ilmenite intergrowths, both of which are subordinate to hercynite. Sapphirine, sillimanite, biotite and zircon are present in trace amounts. Sapphirine occurs with hercynite and magnetite (Fig. 2), whereas sillimanite and biotite are enclosed in prismatine (Fig. 3). The second sample (\#14) is a mass of magnetite collected along the contact between pegmatite and quartzsillimanite-hypersthene-cordierite gneiss. A högbomite-group mineral forms subhedral to euhedral platelets $0.1-0.4 \mathrm{~mm}$ dispersed in magnetite (Fig. 4); small amounts of rutile and corundum are also enclosed, whereas muscovite occurs around the margins.

The only other borosilicate found in this area is tourmaline in pegmatites.

\section{X-ray diffraction}

Single crystal X-ray diffraction (XRD) on a Siemens SMART CCD system gave the following lattice parameters for the högbomite-group mineral, $a=5.71 \AA, c=18.36 \AA$, which indicates the predominance of the $8 \mathrm{H}$ polysome, i.e. the mineral is identified as ferrohögbomite- $2 N 2 S$ (Armbruster, 2002; Hejny et al., 2002).

\section{Chemical composition}

\section{Method}

Concentrations of elements with $Z \geqslant 9$ were determined by M.G. Yates with a wavelength dispersive ARL SEMQ electron microprobe at the University of Maine and by C. Hejny with a wavelength dispersive Cameca SX-50 with the assistance of Edwin Gnos at the University of Bern. Analytical conditions on the ARL were $15 \mathrm{kV}$, accelerating voltage, $10 \mathrm{nA}$ beam current, and a $3 \mu \mathrm{m}$ spot size. Natural silicates and oxides were used as standards and data were processed with a $\varphi(\rho z)$ scheme in which the effect of constituents not analysed with the electron microprobe $\left(\mathrm{H}_{2} \mathrm{O}, \mathrm{B}_{2} \mathrm{O}_{3}\right)$ were included. $\mathrm{F}$ and $\mathrm{Cl}$ were analysed during separate sessions on the ARL 


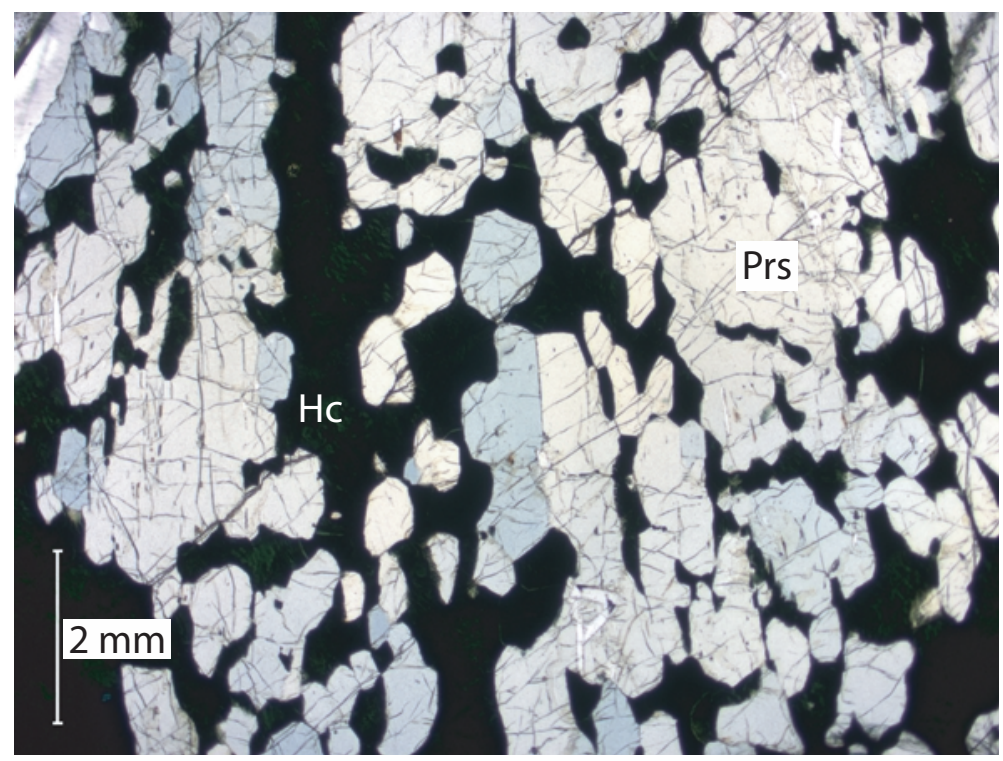

Fig. 1. Photomicrograph of prismatine (Prs)-bearing rock \#15. The differing orientation of the prismatine prisms is evident from variations in colour. The dominant oxide is dark-green hercynite $(\mathrm{Hc})$ riddled with magnetite exsolution. Plain light.

SEMQ, also at $15 \mathrm{kV}$ and $10 \mathrm{nA}$, with an Ovonics $60 \AA$ crystal, using polylithionite $(9.6$ wt.\% F) and scapolite as standards (Grew et al., 1998a). Fluorine counts were fully corrected for peak overlaps, and backgrounds for $\mathrm{F}$ were determined from mean atomic number rather than offsets.

The conditions in the Cameca SX-50 were $15 \mathrm{kV}$ and $14 \mathrm{nA}$. The following minerals and

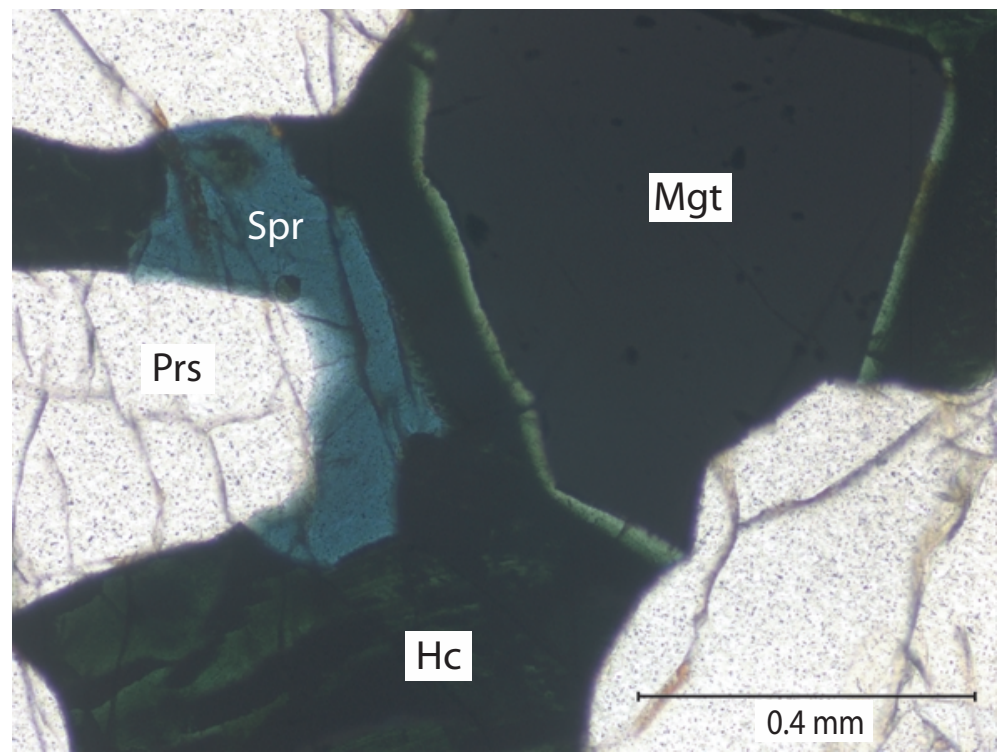

FIG. 2. Photomicrograph of prismatine (Prs), sapphirine (Spr, analysis in Table 1), hercynite (Hc) riddled with magnetite exsolution except in a narrow margin adjacent to magnetite (Mgt). Sample \#15. Plain light. 


\section{E. S. GREWETAL.}

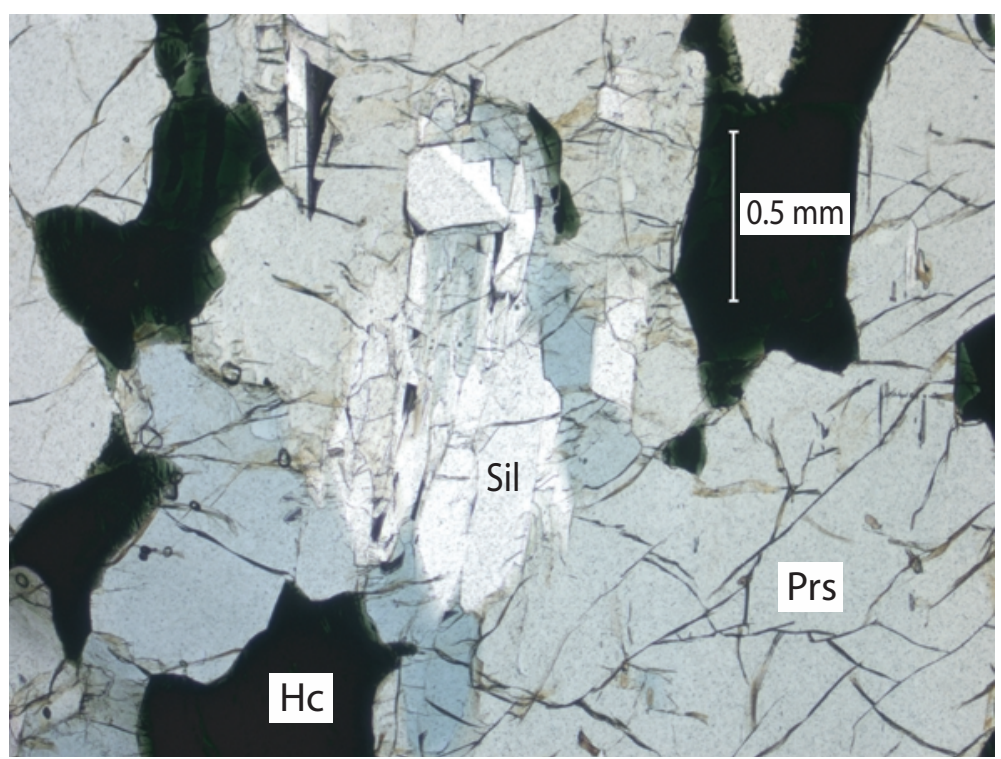

FIG. 3. Photomicrograph of a sillimanite aggregate (Sil, cf. col. 2, Table 2) enclosed in prismatine (Prs). Hc hercynite. Sample \#15. Plain light.

synthetic materials were used as standards:

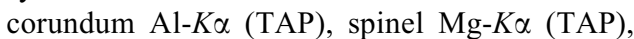

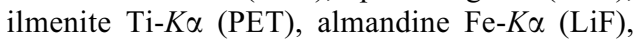
gahnite $\mathrm{Zn}-K \alpha(\mathrm{LiF}), \mathrm{V}_{2} \mathrm{O}_{5} \mathrm{~V}-K \alpha$, eskolaite $\mathrm{Cr}-K \alpha(\mathrm{LiF})$, tephroite $\mathrm{Mn}-K \alpha(\mathrm{LiF}), \mathrm{SnS}_{2}$
$\mathrm{Sn}-\mathrm{K} \alpha(\mathrm{LiF}), \mathrm{NiO} \mathrm{Ni}-K \alpha(\mathrm{LiF}), \mathrm{HgGa}_{2} \mathrm{~S}_{4}$ $\mathrm{Ga}-K \alpha(\mathrm{LiF})$, anorthite $\mathrm{Ca}-K \alpha(\mathrm{PET})$, phlogopite F- $K \alpha$ (TAP), scapolite Cl-K $\alpha$ (PET). The overlap of $\mathrm{V}-K \alpha$ with $\mathrm{Ti}-K \alpha$ on $\mathrm{LiF}$ could not be corrected.

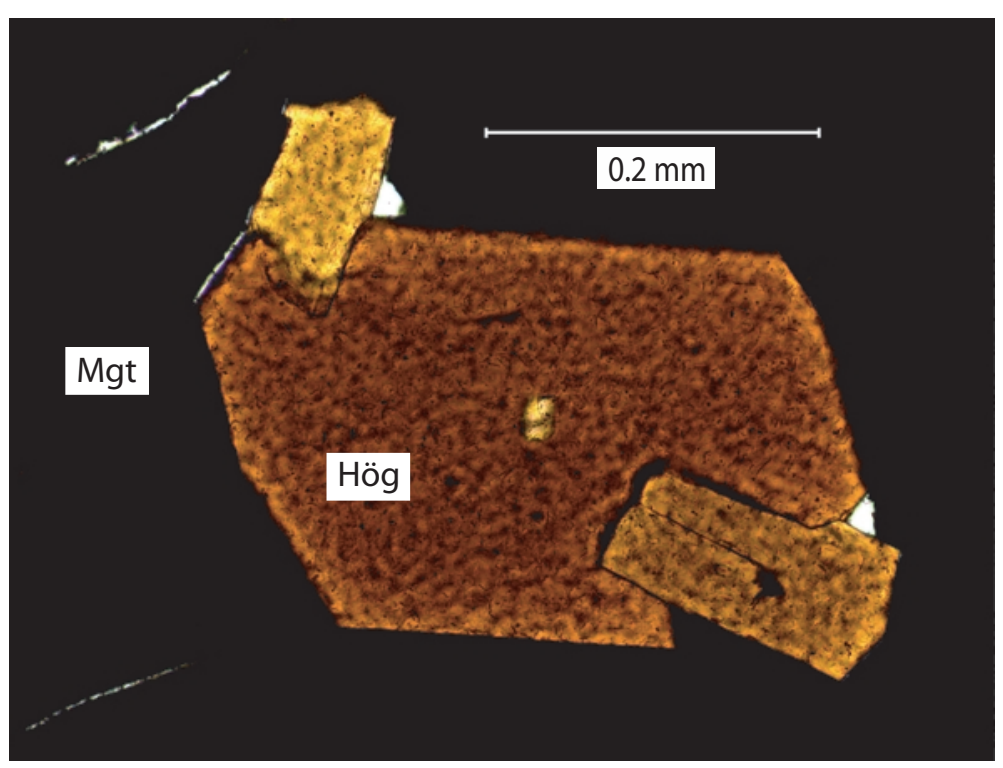

FIG. 4. Photomicrograph of euhedral ferrohögbomite-2N2S grains (Hög) in magnetite (Mgt). Sample \#14. Plain light. 
Lithium, $\mathrm{Be}$ and $\mathrm{B}$ were determined by secondary ion mass spectrometry (SIMS) with a Cameca ims $4 \mathrm{f}$ ion microprobe operated on the University of New Mexico campus by the Institute of Meteoritics. These elements were analysed under the following conditions: ${ }^{16} \mathrm{O}^{-}$ beam accelerated through $10 \mathrm{kV}$, a $15 \mathrm{nA}$ primary beam current, $15 \mu \mathrm{m}$ beam spot diameter, sample voltage offset of $-105 \pm 25 \mathrm{~V}$ and a $150 \mu \mathrm{m}$ secondary ion image field with a $33 \mu \mathrm{m}$ field aperture inserted. Prior to each analysis, the sample surface was cleaned using a rastered ion beam and imaged to better define the location of the analysis. Mass peaks for ${ }^{6.5}$ background $(2 \mathrm{~s})$, ${ }^{7} \mathrm{Li}^{+}$(3 s), ${ }^{9} \mathrm{Be}^{+}(5 \mathrm{~s}),{ }^{11} \mathrm{~B}^{+}(5 \mathrm{~s})$ and ${ }^{30} \mathrm{Si}^{+}(3 \mathrm{~s})$ were counted; and each spot analysis involved ten such counting cycles. These counting times resulted in internal precision of better than $5 \%$ for all elements. The calibration curves were produced using the relationship: $\left[{ }^{7} \mathrm{Li}^{+},{ }^{9} \mathrm{Be}^{+}\right.$or $\left.{ }^{11} \mathrm{~B}^{+} /{ }^{30} \mathrm{Si}^{+}\right)$count ratio $* \mathrm{SiO}_{2}$ wt.\%] vs. element concentration in the following standards (all minerals): dravite, lithian schorl and elbaite for Li and B (Dyar et al., 2001), type khmaralite (2.77 wt.\% BeO) and surinamite no. 2292C for Be (Grew et al. 2000; Barbier et al., 2002), and prismatine no. BM1940,39 for B (Cooper, 1997). The $\mathrm{Li}, \mathrm{Be}$ and $\mathrm{B}$ contents (ppm element or wt.\% oxide) were calculated from ${ }^{7} \mathrm{Li}^{+} \beta{ }^{30} \mathrm{Si}^{+} * \mathrm{SiO}_{2}$, ${ }^{9} \mathrm{Be}^{+} / 30 \mathrm{Si}^{+}{ }^{*} \mathrm{SiO}_{2}$ and ${ }^{11} \mathrm{~B}^{+} /{ }^{30} \mathrm{Si}^{+} * \mathrm{SiO}_{2}$ (count ratio*wt. $\%$ by electron microprobe analyses) with the unknowns corrected using these calibration curves. Several standards, including the ones listed above, were run at various times during the day to monitor and correct for instrument drift. The analyses were performed at mass resolution of $\sim 320$, which is sufficient for the ${ }^{27} \mathrm{Al}^{3+}$ signal not to interfere with the ${ }^{9} \mathrm{Be}^{+}$signal in prismatine and sapphirine, and probably in sillimanite as well. The minimum Be content needed to avoid such interference in Al-rich minerals was estimated by Grew et al. (1998b) to be 0.001 wt. $\% \mathrm{BeO}$, which corresponds to $4 \mathrm{ppm}$ $\mathrm{Be}$ (incorrectly given as $30 \mathrm{ppm} \mathrm{Be}$ by Grew et al., 1998b).

Major and trace elements in the Bok se Puts rocks were determined with a Philips PW1400 and Siemens SRS-1 wavelength-dispersive sequential X-ray fluorescence spectrometers in the Department of Geological Sciences, University of Cape Town (Moore and Waters, 1990). Major elements were analysed by the Norrish fusion method (Norrish and Hutton, 1969); $\mathrm{Na}$ and trace elements by using 5-g pressed briquettes. The data were calibrated with USGS and South African NIMROC standards.

\section{Prismatine}

Compared to prismatine from other localities, the sample from Venugopalapuram has a modest B content and relatively high Fe content; analyses at three different spots indicate minor chemical heterogeneity in terms of $\mathrm{Fe} / \mathrm{Mg}$ ratio, $\mathrm{B}$ and $\mathrm{F}$ contents (Table 1). Although we are not able to measure the $\mathrm{Fe}^{3+} / \mathrm{Fe}^{2+}$ ratio directly, we suspect that substantial $\mathrm{Fe}^{3+}$ is present. The relatively elevated $\mathrm{Fe}^{3+}$ content and $\mathrm{Fe}^{3+} / \mathrm{Fe}^{2+}$ ratio, respectively, of associated sillimanite (Table 2) and sapphirine (Table 1) suggest that the prismatine $\mathrm{Fe}^{3+} / \Sigma \mathrm{Fe}$ ratio could be at least 0.20 , a relatively high value for the kornerupine-prismatine series (Grew et al., 1999). The Venugopalapuram prismatine is one of the two most F-rich reported, cf. 0.94 wt.\% F/0.374 F per 21.5 O from Paderu (Cooper, 1997; Hawthorne et al., in prep.; this paper, Fig. 5).

\section{Fe-Ti oxides}

Overall, 23 individual grains of the högbomitegroup mineral were analysed (Table 3 ). In all but one grain, the main variation is $\mathrm{Zn}$ substitution for other divalent cations, mainly $\mathrm{Fe}^{2+}$ and $\mathrm{Mg}$, whereas $\mathrm{Ti}$ content is constant (Fig. $6 a, b$ ). The calculated $\mathrm{Fe}^{3+} / \Sigma \mathrm{Fe}$ ratio and $(\mathrm{Al}+\mathrm{Ga})$ content are more scattered, but appear to be, like $\mathrm{Ti}$, independent of variations among the divalent cations (Figs $6 c, 7)$. Similar relationships were reported in ferrohögbomite- $2 N 2 S$ from Sinnan Rocks, Antarctica (Grew et al., 1990b; Hejny et al., 2002). The compositions of grains $2-21,2 \& 4$ are consistent with identification as ferrohögbomite- $2 N 2 S$ using XRD on another grain from the same sample. One grain (\#1) has a markedly higher $\mathrm{Ti}$ and lower $\mathrm{Al}+\mathrm{Ga}$ content; the equation $0.5 \mathrm{Ti}+0.5\left(\mathrm{Fe}^{2+}+\mathrm{Mg}+\mathrm{Zn}\right) \approx 1(\mathrm{Al}+\mathrm{Ga}+$ $\left.\mathrm{Fe}^{3+}\right)$ on a $32(\mathrm{O}, \mathrm{OH})$ basis relates its composition to those of the others. This grain could be another polysome, but identification is not possible on the basis of composition alone.

The $\mathrm{TiO}_{2}$ and $\mathrm{Fe}_{2} \mathrm{O}_{3}$ contents of the Venugopalapuram ferrohögbomite- $2 N 2 S$ are typical for ferrohögbomite-2N2S (Hejny et al., 2002). It contains more $\mathrm{Ga}$ than most other högbomite-group minerals in which $\mathrm{Ga}$ had been sought, but its $\mathrm{Ga}$ content is not the highest reported; up to 1.79 wt. $\% \mathrm{Ga}_{2} \mathrm{O}_{3}$ has been 
TABLE 1. Analyses of prismatine (Prs) and sapphirine (Spr) in sample \#15.

\begin{tabular}{|c|c|c|c|c|}
\hline $\begin{array}{l}\text { Mineral } \\
\text { Grain }\end{array}$ & $\begin{array}{c}\text { Prs } \\
1\end{array}$ & $\begin{array}{c}\text { Prs } \\
2\end{array}$ & $\begin{array}{c}\text { Prs } \\
3\end{array}$ & $\begin{array}{c}\text { Spr } \\
1\end{array}$ \\
\hline \multicolumn{5}{|l|}{ Wt.\% } \\
\hline $\mathrm{SiO}_{2}$ & 29.72 & 29.92 & 29.00 & 13.44 \\
\hline $\mathrm{TiO}_{2}$ & 0.31 & 0.32 & 0.33 & 0.08 \\
\hline $\mathrm{Al}_{2} \mathrm{O}_{3}$ & 41.21 & 40.71 & 41.84 & 56.48 \\
\hline $\mathrm{Fe}_{2} \mathrm{O}_{3}$ & - & - & - & 4.98 \\
\hline $\mathrm{FeO}$ & 9.00 & 8.94 & 8.68 & 9.07 \\
\hline $\mathrm{MnO}$ & 0.11 & 0.11 & 0.14 & 0.12 \\
\hline $\mathrm{MgO}$ & 14.72 & 14.85 & 15.08 & 14.76 \\
\hline $\mathrm{CaO}$ & 0.03 & 0.04 & 0.03 & 0.00 \\
\hline $\mathrm{K}_{2} \mathrm{O}$ & 0.00 & 0.00 & 0.00 & 0.00 \\
\hline $\mathrm{Na}_{2} \mathrm{O}$ & 0.06 & 0.06 & 0.05 & 0.00 \\
\hline $\mathrm{Li}_{2} \mathrm{O}$ & 0.03 & 0.03 & 0.03 & 0.01 \\
\hline $\mathrm{BeO}$ & 0.05 & 0.05 & 0.05 & 0.04 \\
\hline $\mathrm{B}_{2} \mathrm{O}_{3}$ & 2.84 & 3.03 & 2.91 & 0.35 \\
\hline $\mathrm{F}$ & 1.01 & 0.91 & 0.97 & - \\
\hline $\mathrm{Cl}$ & 0.00 & 0.00 & 0.00 & - \\
\hline $\mathrm{H}_{2} \mathrm{O}$ & 0.72 & 0.76 & 0.74 & - \\
\hline $\mathrm{F}=\mathrm{O}$ & -0.43 & -0.39 & -0.41 & - \\
\hline Sum & 99.38 & 99.36 & 99.44 & 99.33 \\
\hline \multicolumn{5}{|l|}{ ppm } \\
\hline $\mathrm{Li}$ & 140 & 146 & 143 & 26 \\
\hline $\mathrm{Be}$ & 175 & 171 & 166 & 137 \\
\hline B & - & - & - & 1100 \\
\hline \multicolumn{5}{|l|}{ Formulae } \\
\hline $\mathrm{O}$ & 21.5 & 21.5 & 21.5 & 20 \\
\hline $\mathrm{Si}$ & 3.725 & 3.750 & 3.632 & 1.647 \\
\hline $\mathrm{Ti}$ & 0.029 & 0.030 & 0.031 & 0.008 \\
\hline $\mathrm{Al}$ & 6.087 & 6.013 & 6.177 & 8.159 \\
\hline $\mathrm{Fe}^{3+}$ & - & - & - & 0.459 \\
\hline $\mathrm{Fe}^{2+}$ & 0.943 & 0.937 & 0.910 & 0.929 \\
\hline $\mathrm{Mn}$ & 0.012 & 0.012 & 0.015 & 0.013 \\
\hline $\mathrm{Mg}$ & 2.749 & 2.774 & 2.816 & 2.696 \\
\hline $\mathrm{Ca}$ & 0.004 & 0.005 & 0.004 & 0.000 \\
\hline $\mathrm{Na}$ & 0.014 & 0.014 & 0.011 & 0.000 \\
\hline $\mathrm{Li}$ & 0.015 & 0.016 & 0.015 & 0.003 \\
\hline $\mathrm{Be}$ & 0.015 & 0.014 & 0.014 & 0.011 \\
\hline $\mathrm{B}$ & 0.615 & 0.655 & 0.629 & 0.075 \\
\hline Sum & 14.209 & 14.220 & 14.255 & 14.000 \\
\hline $\mathrm{F}$ & 0.402 & 0.362 & 0.384 & - \\
\hline $\mathrm{OH}$ & 0.598 & 0.638 & 0.616 & - \\
\hline
\end{tabular}

Note: All Fe analysed as $\mathrm{FeO}$. $\mathrm{Li}, \mathrm{Be}$ and $\mathrm{B}$ determined by ion microprobe (SIMS). Ferric/ ferrous ratio calculated in sapphirine assuming 14 cations $/ 20$ oxygens. $\mathrm{H}_{2} \mathrm{O}$ calculated in prismatine

reported (Grew et al., 2000; Hejny et al., 2002; Hejny and Armbruster, 2002). The amounts of V,
TABLE 2. Composition of sillimanite in sample \#15.

\begin{tabular}{|c|c|c|}
\hline Grain & 1 & 2 \\
\hline \multicolumn{3}{|l|}{ Wt.\% } \\
\hline $\mathrm{SiO}_{2}$ & 36.68 & 36.24 \\
\hline $\mathrm{B}_{2} \mathrm{O}_{3}$ & 0.26 & 0.19 \\
\hline $\mathrm{TiO}_{2}$ & 0.04 & 0.04 \\
\hline $\mathrm{Al}_{2} \mathrm{O}_{3}$ & 61.13 & 61.36 \\
\hline $\mathrm{Fe}_{2} \mathrm{O}_{3}$ & 1.75 & 1.60 \\
\hline $\mathrm{MnO}$ & 0.00 & 0.00 \\
\hline $\mathrm{MgO}$ & 0.13 & 0.12 \\
\hline \multicolumn{3}{|l|}{ ppm } \\
\hline $\mathrm{Li}$ & $<0.1$ & $<0.1$ \\
\hline $\mathrm{Be}$ & 13 & 10 \\
\hline B & 800 & 594 \\
\hline Sum & 99.99 & 99.55 \\
\hline \multicolumn{3}{|c|}{ Formulae per $5 \mathrm{O}$} \\
\hline $\mathrm{Si}$ & 0.995 & 0.987 \\
\hline B & 0.012 & 0.009 \\
\hline $\mathrm{Ti}$ & 0.001 & 0.001 \\
\hline $\mathrm{Al}$ & 1.954 & 1.971 \\
\hline $\mathrm{Fe}^{3+}$ & 0.036 & 0.033 \\
\hline $\mathrm{Mg}$ & 0.005 & 0.005 \\
\hline Sum & 3.003 & 3.005 \\
\hline
\end{tabular}

Note: All Fe calculated as $\mathrm{Fe}_{2} \mathrm{O}_{3}$. $\mathrm{Li}, \mathrm{Be}, \mathrm{B}$ determined by ion microprobe (SIMS)

$\mathrm{Cr}, \mathrm{Ni}$ and $\mathrm{Sn}$ are close to the limits of detection or below it.

The host magnetite contains negligible $\mathrm{Ti}$; the most abundant impurities are $\mathrm{Al}_{2} \mathrm{O}_{3}$ and $\mathrm{MnO}$ (0.2-0.3 wt. \% each). Much subordinate hematite contains $4 \% \quad \mathrm{TiO}_{2}$; rutile, 0.8 wt. $\% \mathrm{FeO}$; corundum contains 0.5 wt. $\% \quad \mathrm{Fe}_{2} \mathrm{O}_{3}$ and 0.09 wt. $\% \mathrm{Ga}_{2} \mathrm{O}_{3}$.

Gallium and $\mathrm{Zn}$ are below detection and $\mathrm{Cr}$ is negligible in hercynite in sample \#15 (Table 3).

\section{Distribution of the light elements in the silicates}

\section{Boron}

Sillimanite and sapphirine incorporate B (Tables 1, 2). In general, the $\mathrm{B}$ contents of these two minerals increase modestly with increasing B content of associated kornerupine-prismatine until the latter mineral's B content reaches $0.65-0.9$ B per formula unit, at which point their B contents increase more markedly (Fig. 8). The kink in the trend appears to be related to the maximum B 


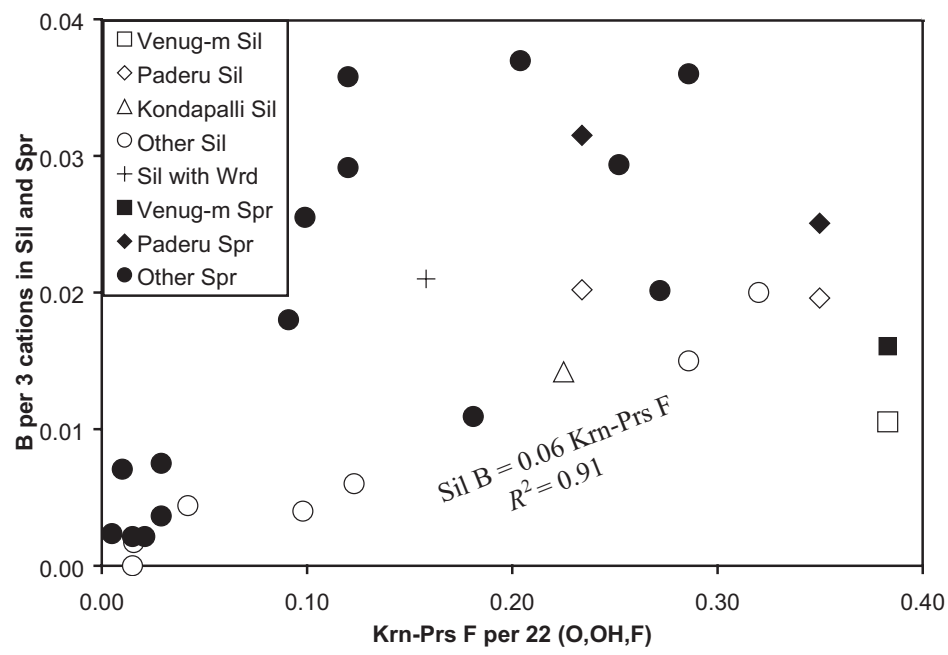

FIG. 5. Boron contents of sillimanite (Sil) sapphirine (Spr) as a function of kornerupine-prismatine (Krn-Prs) F content. Sources: Grew et al. (1990a, 1992, 1998a) and references cited therein for other sillimanite and sapphirine; Grew et al. (1997) for sillimanite associated with werdingite (Wrd); this study for Venugopalapuram (Venug-m). The line is a least-squares fit to the data excluding sillimanite from Venugopalapuram and sillimanite associated with werdingite.

permissible in prismatine $-1 \mathrm{~B} / 21.5 \mathrm{O}$ (e.g. Grew, 2002a); the B content of the Venugopalapuram prismatine is below this limit. A linear increase of sillimanite B content with kornerupine-prismatine $\mathrm{F}$ was noted by Grew et al. (1990a) and Grew (2002a) (reproduced here in Fig. 5); sapphirine $\mathrm{B} /$ / cations ratio exceeds that of sillimanite, but otherwise shows no relationship to F. Exceptions to the linear trend are the newest data on sillimanite, i.e. sillimanite associated with werdingite and the Venugopalapuram sillimanite. The deviation of the werdingite-bearing sample is not surprising because B-bearing sillimanite is interpreted to contain werdingite-like domains (Niven et al., 1991; Werding and Schreyer, 1992), and thus more B might be expected in sillimanite associated with werdingite. However, the relatively low values of the Venugopalapuram sillimanite and sapphirine calls into question the generality of the linear relationship. Grew et al. (1990a) attributed the relationship between sillimanite $\mathrm{B}$ and kornerupine-prismatine $\mathrm{F}$ to temperature and water activity: as temperature increases and $a_{\mathrm{H}_{2} \mathrm{O}}$ decreases, the OH-F phases kornerupine and prismatine become increasingly F rich and solid solution of werdingite increases in sillimanite. Moreover, the rocks in the Venugopalapuram area were subjected to ultrahigh-temperature granulite-facies conditions, which resulted in hypersthene + sillimanite + quartz and sapphirine + quartz assemblages (Kamineni and Rao, 1988; Grew et al., 2001), conditions comparable to those experienced by rocks in nearby Paderu (e.g. Pal and Bose, 1997; Bhattacharya and Kar 2002). The discrepancy suggests that the linear relationship could be a coincidence resulting from the few samples studied, and that further examples will show that there is no simple relationship between sillimanite $\mathrm{B}$ and kornerupine-prismatine $\mathrm{F}$ contents.

\section{Beryllium}

The Venugopalapuram sapphirine-prismatine pair is the second richest in Be reported and the two richest pairs suggest a preference of $\mathrm{Be}$ for kornerupine-prismatine over sapphirine (Fig. 9), itself a Be sink in high-grade metamorphic rocks (e.g. Grew, 2002b). In contrast, distribution in Bepoor pairs suggest the reverse preference, but interpretation of this preference is complicated by the difficulty of measuring small amounts of Be in Al-rich minerals at low mass resolution with the ion microprobe (e.g. Grew et al., 1990a). Analysis of coexisting kornerupine-prismatine sapphirine pairs at higher mass resolution is needed to clarify Be distribution between these two minerals. 


\section{E. S. GREWETAL.}

TABLE 3. Compositions of hercynite (Hc) and högbomite-group minerals (Hög).

\begin{tabular}{lcccccc}
\hline Mineral & $\mathrm{Hc}$ & $\mathrm{Hc}$ & $\mathrm{Hög}$ & $\mathrm{Hög}$ & \multicolumn{1}{c}{$\mathrm{Hög}$} & \multicolumn{1}{c}{$\mathrm{Hög}$} \\
Sample $\#$ & 15 & 15 & 14 & 14 & 14 & 14 \\
Section & - & - & 1 & 2 & 2 & 2 \\
Grain & 1 & 2 & $2 \& 4$ & 1 & 5 & 19 \\
\hline $\mathrm{Wt} \%$ & & & & & & \\
$\mathrm{TiO}_{2}$ & 0.00 & 0.00 & 4.57 & 7.38 & 4.59 & 4.51 \\
$\mathrm{SnO}_{2}$ & - & - & 0.00 & 0.02 & 0.01 & 0.08 \\
$\mathrm{Al}_{2} \mathrm{O}_{3}$ & 61.11 & 59.32 & 58.83 & 56.87 & 59.60 & 60.52 \\
$\mathrm{~V}_{2} \mathrm{O}_{3}$ & - & - & - & 0.14 & 0.17 & 0.01 \\
$\mathrm{Cr}_{2} \mathrm{O}_{3}$ & 0.11 & 0.00 & 0.00 & 0.00 & 0.01 & 0.00 \\
$\mathrm{Ga}_{2} \mathrm{O}_{3}$ & 0.00 & 0.00 & 0.56 & 0.92 & 0.42 & 0.54 \\
$\mathrm{Fe}_{2} \mathrm{O}_{3}$ & 2.97 & 4.78 & 9.67 & 5.75 & 8.93 & 8.46 \\
$\mathrm{FeO}$ & 24.91 & 26.19 & 12.60 & 12.59 & 11.52 & 11.12 \\
$\mathrm{MnO}$ & 0.10 & 0.10 & 0.60 & 1.08 & 0.92 & 1.13 \\
$\mathrm{MgO}$ & 10.90 & 9.91 & 3.82 & 4.56 & 3.98 & 4.85 \\
$\mathrm{ZnO}$ & 0.00 & 0.00 & 7.22 & 7.79 & 7.90 & 6.51 \\
$\mathrm{NiO}$ & - & - & - & 0.06 & 0.01 & 0.01 \\
$\mathrm{H}_{2} \mathrm{O}$ & - & - & 1.40 & 1.39 & 1.40 & 1.41 \\
$\mathrm{Sum}$ & 100.10 & 100.29 & 99.27 & 98.54 & 99.45 & 99.16
\end{tabular}

Formulae

\begin{tabular}{lccrrrr}
$\mathrm{O}$ & 4 & 4 & 31 & 31 & \multicolumn{1}{c}{31} & \multicolumn{1}{c}{31} \\
$\mathrm{Ti}$ & 0.000 & 0.000 & 0.738 & 1.201 & 0.737 & 0.719 \\
$\mathrm{Sn}$ & - & - & 0.000 & 0.002 & 0.001 & 0.007 \\
$\mathrm{Al}$ & 1.938 & 1.902 & 14.885 & 14.506 & 15.003 & 15.122 \\
$\mathrm{~V}$ & - & & - & 0.023 & 0.028 & 0.002 \\
$\mathrm{Cr}$ & 0.002 & 0.000 & 0.000 & 0.000 & 0.002 & 0.000 \\
$\mathrm{Ga}$ & 0.000 & 0.000 & 0.077 & 0.128 & 0.057 & 0.073 \\
$\mathrm{Fe}^{3+}$ & 0.060 & 0.098 & 1.562 & 0.936 & 1.435 & 1.350 \\
$\mathrm{Fe}^{2+}$ & 0.561 & 0.596 & 2.263 & 2.278 & 2.057 & 1.971 \\
$\mathrm{Mn}$ & 0.002 & 0.002 & 0.109 & 0.197 & 0.167 & 0.202 \\
$\mathrm{Mg}$ & 0.437 & 0.402 & 1.222 & 1.472 & 1.266 & 1.532 \\
$\mathrm{Zn}$ & 0.000 & 0.000 & 1.144 & 1.245 & 1.246 & 1.019 \\
$\mathrm{Ni}$ & - & - & - & 0.011 & 0.002 & 0.002 \\
$\mathrm{Sum}$ & 3.000 & 3.000 & 22.000 & 22.000 & 22.000 & 22.000 \\
$\mathrm{H}$ & - & - & 2.000 & 2.000 & 2.000 & 2.000 \\
$X_{\mathrm{Mg}}$ & 0.438 & 0.403 & 0.351 & 0.393 & 0.381 & 0.437
\end{tabular}

Note: All Fe analysed as $\mathrm{FeO}$. F, $\mathrm{Cl}$ and $\mathrm{Ca}$ are below detection in ferrohögbomite$2 N 2 S$. Ferric/ferrous ratio calculated in hercynite assuming 2 cations $/ 3$ oxygens, and in ferrohögbomite- $2 N 2 S$ assuming 22 cations $/ 31$ oxygens. $\mathrm{H}_{2} \mathrm{O}$ calculated in högbomite-group minerals assuming $\mathrm{OH}=2 / 31$ oxygens. $X_{\mathrm{Mg}}=\mathrm{Mg} /\left(\mathrm{Mg}+\mathrm{Fe}^{2+}\right)$. Analyst: Col. 1-3 - M.G. Yates; Col. 4-6 - C. Hejny

\section{Lithium}

In general, this alkali is preferentially incorporated in kornerupine-prismatine relative to sapphirine (Grew et al., 1990a), and this preference is evident in the Venugopalapuram assemblage (Table 1).

\section{Origin of the boron enrichment}

The Venugopalapuram prismatine-rich lens is one of the few examples of rocks enriched in $\mathrm{Al}, \mathrm{Fe}$ and $\mathrm{B}$ in relatively high-temperature granulitefacies rocks (Table 4). These Al-Fe-B-rich rocks appear to be restricted to lenses a few tens of 

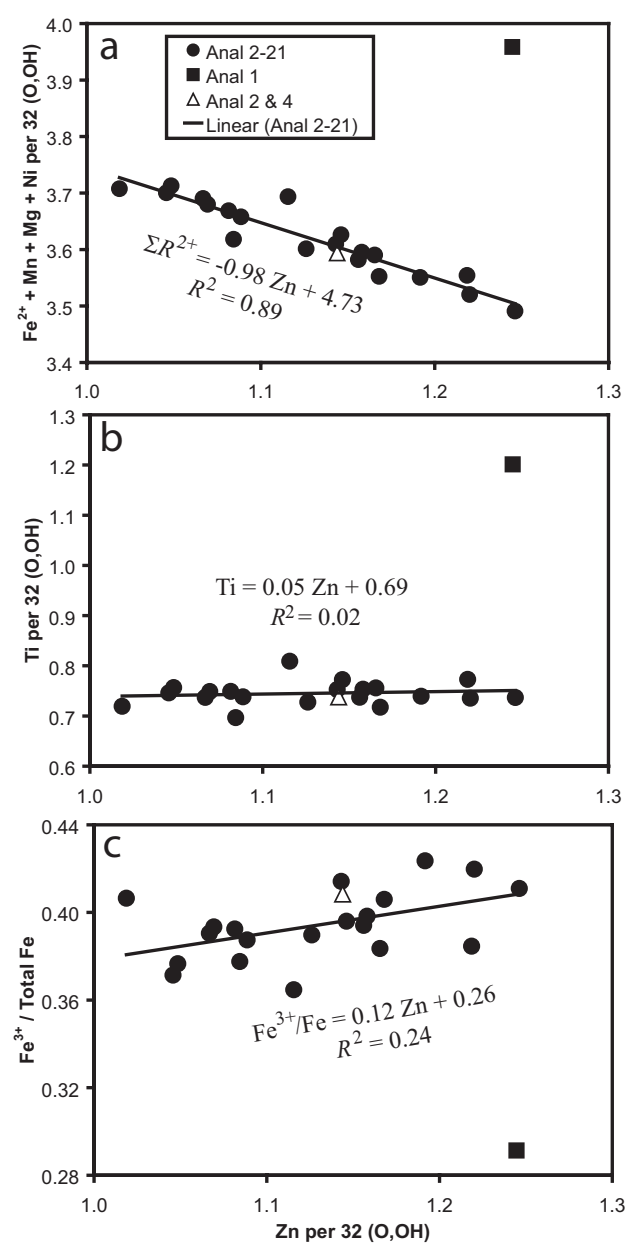

Fig. 6. Variations of total divalent cations $\left(\Sigma R^{2+}\right)$, Ti and $\mathrm{Fe}^{3+} / \mathrm{Fe}$ ratio with $\mathrm{Zn}$ in ferrohögbomite- $2 N 2 S$ from Venugopalapuram calculated in terms of $30 \mathrm{O}$ and $2 \mathrm{OH}$. Grains 1-21 were analysed by C. Hejny; grains 2 ( 3 points) and 4 were analysed by M.G. Yates in another section. The lines are least-squares fits.

centimetres thick where found in situ, and are typically associated with similar rocks lacking borosilicate: rocks enriched in sillimanite, hercynite, and ilmenite rock at Bok se Puts (Fig. 10) and the ferrohögbomite- $2 S 2 N$-bearing magnetite lens at Venugopalapuram. The B-rich rocks are silica-undersaturated, whereas associated Al-Fe rocks lacking borosilicate are quartz-bearing in some cases. Relatively high $f_{\mathrm{O}_{2}}$ in the Al-Fe-Brich rocks is indicated by the presence of hematite or hematite lamellae in ilmenite and relatively high sillimanite $\mathrm{Fe}_{2} \mathrm{O}_{3}$ contents.
Only the Bok se Puts rocks have been analysed (Table 5). Like other upper amphibolite and granulite-facies aluminous rocks containing borosilicates (e.g. Grew, 2002a), the Bok se Puts borosilicate rock is depleted in $\mathrm{Ca}$ and $\mathrm{Na}$ and enriched in $\mathrm{Mg}$ and $\mathrm{Fe}$; additionally it is depleted in $\mathrm{K}$; the small quantities of biotite and absence of feldspar (except anorthite at Urungwe and possible K-feldspar at Labwor) suggest depletion in $\mathrm{Na}, \mathrm{K}$ and $\mathrm{Ca}$ in the other rocks as well. However, kornerupine-prismatine has incorporated considerable Li (Table 4), suggesting little depletion of this alkali. Despite the high $\mathrm{Fe}$ content, the ferromagnesian silicates are $\mathrm{Mg}$ dominant (e.g. Table 1); much $\mathrm{Fe}^{2+}$ is combined with $\mathrm{Ti}, \mathrm{Fe}^{3+}$ and $\mathrm{Al}$ in the oxide phases.

The Al-Fe \pm B-rich lenses are commonly found in pelitic gneisses, for example, gneisses containing orthopyroxene + sillimanite + cordierite (Venugopalapuram), or cordierite, garnet and/or sillimanite (Urungwe) or along the contacts between cordierite-sillimanite gneiss and biotite gneiss (Bok se Puts, Fig. 10), whereas at Labwor, the lenses occur in mafic granulite. The host rocks for the Paderu borosilicates are not known; by analogy with other sapphirine-bearing rocks from Paderu, the borosilicate-rich rocks could have originated as lenses in khondalite (sillimanite-garnet metapelite) or along the contacts between khondalite and mafic granulite (Lal et al., 1987), or as lenses in quartzofeldspathic gneisses such as leptynite, granite and charnockite (Pal and Bose, 1997; Bhattacharya and Kar, 2002).

In general, granulite-facies rocks are depleted in $B$ so that any enrichment raises the question of what mechanism can counter the effects of devolatilization and anatexis (e.g. Leeman and Sisson, 2002). In other words, what mechanism would explain the mineralogical and chemical features of the rocks listed in Table 4? One explanation is that metamorphism was not isochemical and the present composition resulted not only from the precursor composition, but also from various processes associated with granulitefacies metamorphism. One possibility is that B was introduced metasomatically during metamorphism, e.g. by an anatectic process (Anderson, 1975) or from an intrusion. The $\mathrm{Al}-\mathrm{Fe} \pm \mathrm{B}$ and associated rocks are intruded by pegmatite at Urungwe and Labwor, but tourmaline is found in pegmatite only at Bok se Puts and Venugopalapuram. The tourmaline-bearing pegmatites were emplaced after the major metamorphic events during which 


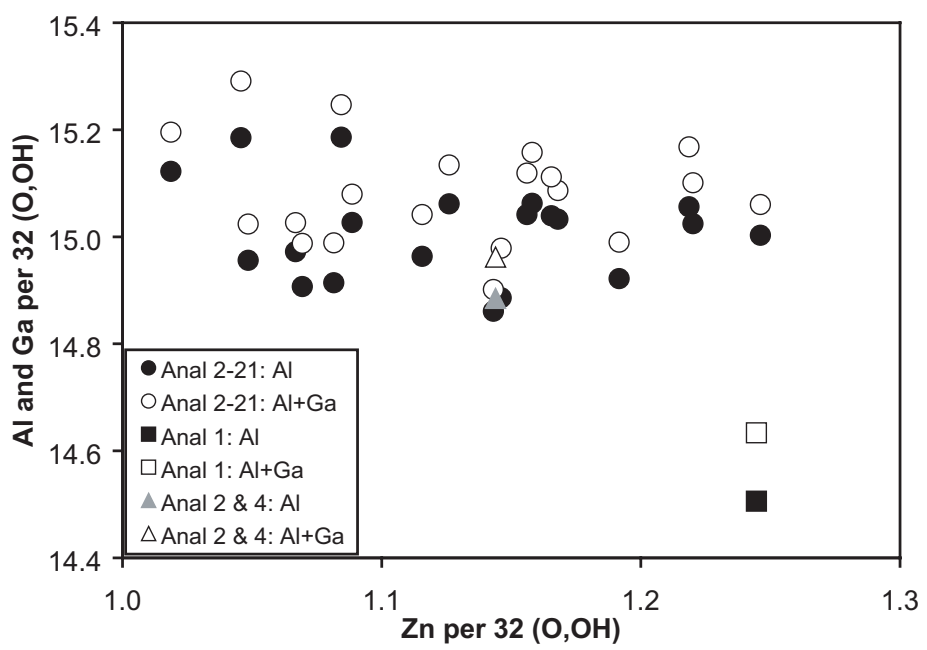

FIG. 7. Variations of $\mathrm{Al}$ and $\mathrm{Ga}$ with $\mathrm{Zn}$ in ferrohögbomite- $2 N 2 S$ from Venugopalapuram calculated in terms of $30 \mathrm{O}$ and $2 \mathrm{OH}$. For grain reference, see Fig. 6.

the other borosilicates crystallized at Bok se Puts, and it is possible that the pegmatites at Venugopalapuram are also post-metamorphic and would not have contributed $\mathrm{B}$ to the prismatinerich lens.

Treloar (1995) proposed that the Urungwe Brich rock was an extremely refractory restite into which $\mathrm{B}$ was partitioned relative to the melt; Bhattacharya and Kar (2002) inferred a role for melting in the metamorphism of sapphirine- bearing rocks at Paderu. The absence of evidence for melting in the B-rich layer at Bok se Puts could be the result of complete removal of melt. But such melting would also be expected to deplete a rock in B given the ready solubility of this element in granitic melts (e.g. Dingwell et al., 2002), so that a melting process in the areas listed in Table 4 should have left a restite depleted in B.

Alternatively, the $\mathrm{Al}-\mathrm{Fe} \pm \mathrm{B}$-rich rocks resulted from a roughly isochemical metamorphism of a

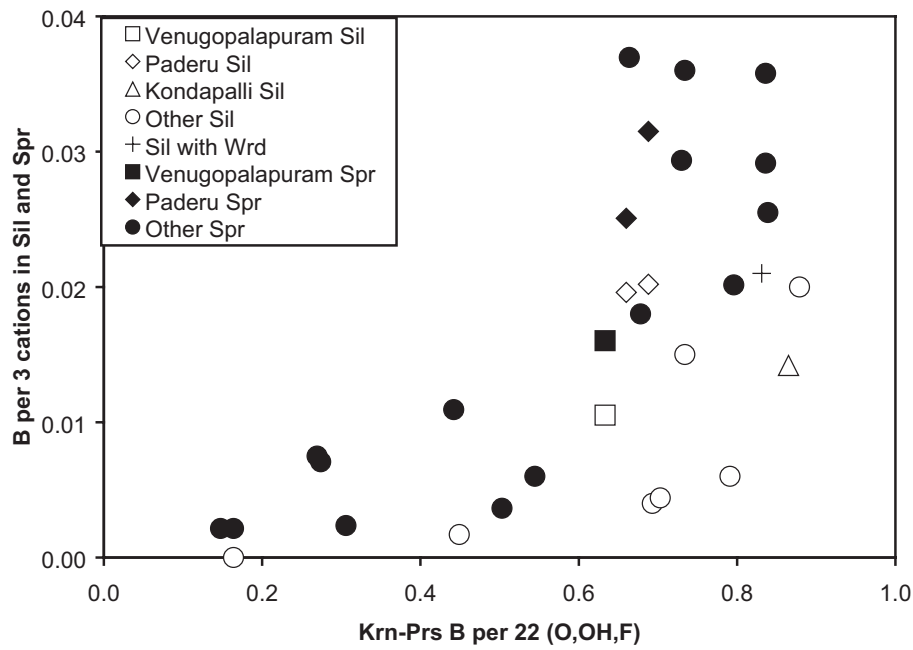

FIG. 8. Boron contents of associated sillimanite (Sil), sapphirine (Spr) and kornerupine-prismatine. Sources: same as Fig. 5. Wrd - werdingite. 


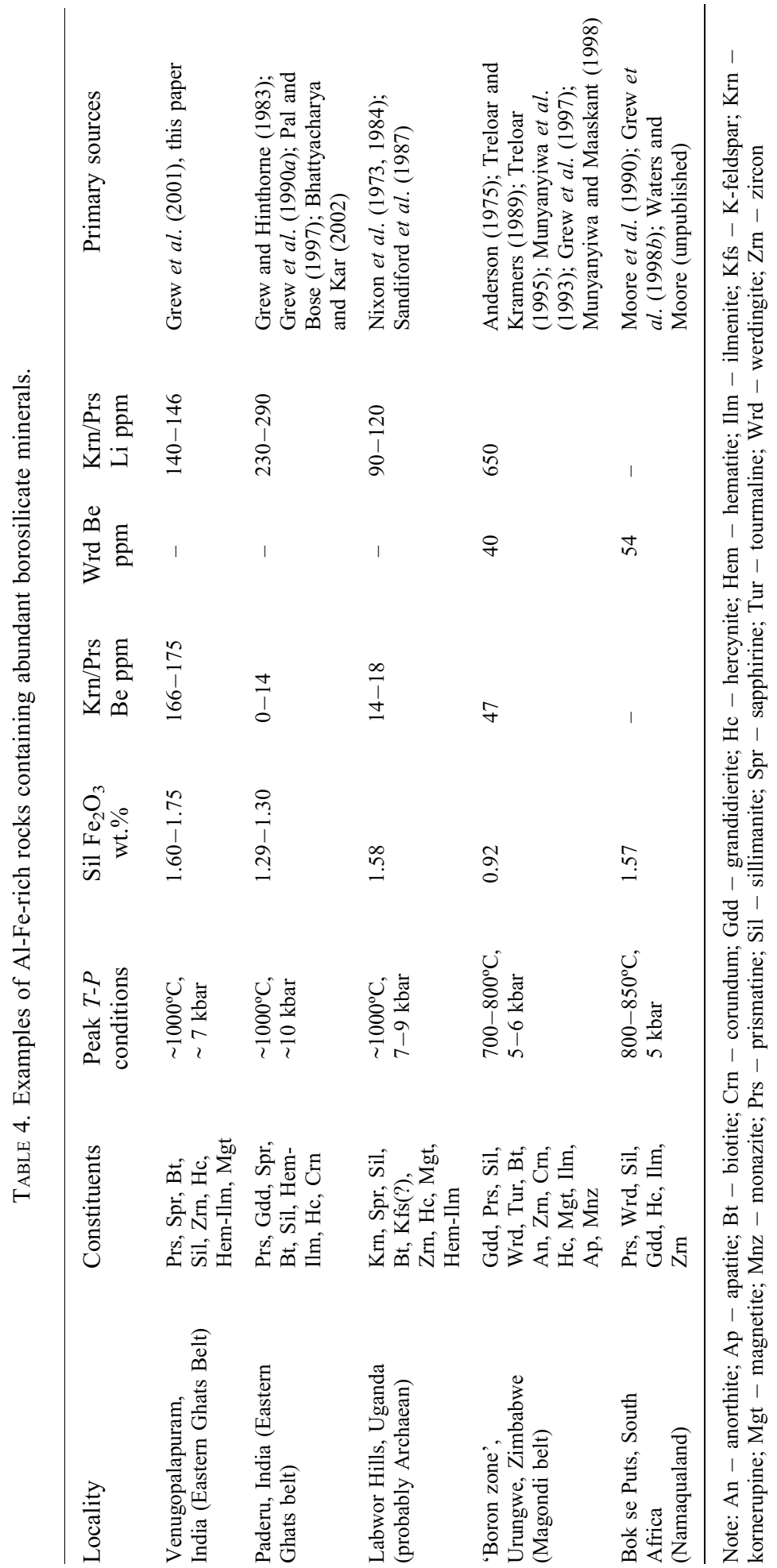


Table 5. Analyses of rocks from Bok se Puts, Namaqualand, South Africa.

\begin{tabular}{|c|c|c|c|}
\hline Sample & $\begin{array}{c}\text { Prismatine } \\
\text { rock } \\
\text { VP-49 }\end{array}$ & $\begin{array}{c}\text { Spinel- } \\
\text { magnetite } \\
\text { rock } \\
\text { VP-48 }\end{array}$ & $\begin{array}{c}\text { Cordierite- } \\
\text { sillimanite } \\
\text { gneiss } \\
\text { VP-50 }\end{array}$ \\
\hline \multicolumn{4}{|l|}{ Wt. $\%$} \\
\hline $\mathrm{SiO}_{2}$ & 21.23 & 0.82 & 73.16 \\
\hline $\mathrm{TiO}_{2}$ & 2.48 & 2.48 & 0.61 \\
\hline $\mathrm{Al}_{2} \mathrm{O}_{3}$ & 46.38 & 47.44 & 13.83 \\
\hline $\mathrm{FeO}$ & 19.94 & 44.84 & 4.76 \\
\hline $\mathrm{MnO}$ & 0.41 & 0.60 & 0.09 \\
\hline $\mathrm{MgO}$ & 7.43 & 5.22 & 1.56 \\
\hline $\mathrm{CaO}$ & 0.08 & 0.02 & 0.79 \\
\hline $\mathrm{Na}_{2} \mathrm{O}$ & 0.03 & 0.03 & 0.60 \\
\hline $\mathrm{K}_{2} \mathrm{O}$ & 0.04 & 0.04 & 2.70 \\
\hline $\mathrm{P}_{2} \mathrm{O}_{5}$ & 0.13 & 0.02 & 0.12 \\
\hline LOI & 0.07 & 2.45 & 1.12 \\
\hline $\mathrm{H}_{2} \mathrm{O}^{-}$ & 0.1 & 0.05 & 0.12 \\
\hline Total & 98.28 & 100.01 & 99.63 \\
\hline \multicolumn{4}{|l|}{ ppm } \\
\hline $\mathrm{Sc}$ & 79 & 29 & 15 \\
\hline V & 221 & 477 & 59 \\
\hline $\mathrm{Cr}$ & 282 & 508 & 73 \\
\hline Co & 52 & 124 & 17 \\
\hline $\mathrm{Ni}$ & 91 & 301 & 21 \\
\hline $\mathrm{Cu}$ & 41 & $<2$ & 7 \\
\hline $\mathrm{Zn}$ & 506 & 2217 & 78 \\
\hline $\mathrm{Rb}$ & 5 & 2 & 168 \\
\hline $\mathrm{Sr}$ & 27 & $<2$ & 58 \\
\hline Y & 56 & 19 & 44 \\
\hline $\mathrm{Zr}$ & 1117 & 1626 & 316 \\
\hline $\mathrm{Nb}$ & 32 & 37 & 14 \\
\hline $\mathrm{Ba}$ & 76 & 30 & 692 \\
\hline $\mathrm{La}$ & 187 & 69 & 53 \\
\hline $\mathrm{Ce}$ & 390 & 135 & 113 \\
\hline $\mathrm{Nd}$ & 191 & 71 & 57 \\
\hline $\mathrm{Pb}$ & 12 & 6 & 16 \\
\hline Th & 77 & 27 & 18 \\
\hline $\mathrm{U}$ & 2 & $<3$ & 2 \\
\hline
\end{tabular}

Note: Analyst - J.M. Moore. Analysis for VP-49 was also reported in Grew (2002a). LOI - loss on ignition

distinctive B-rich sedimentary precursor. Although anatexis undoubtedly affected the bulk composition of the rocks, the presently observed composition still has many features attributable to the original composition. A notable characteristic of the sequence of rock types at Bok se Puts is asymmetry (Fig. 10), which, together with the unusual composition of the oxide and borosilicate rocks, suggests derivation from metamorphism of a duricrust that capped a lateritic profile. Boron enrichments are possible in lateritic profiles (Moore and Waters, 1990); e.g. Angélica et al. (1996) reported $17 \%$ residual tourmaline, largely dravite, in latosol derived from weathering of lateritic iron crust in the Águas Claras deposit, Amazon region, Brazil. The latosol is mainly composed of kaolinite, goethite, gibbsite, hematite and quartz. A similar situation might pertain to the Loulo gold deposit, Mali, where $1500 \mathrm{ppm}$ $\mathrm{B}$ were reported in a truncated weathering profile over tourmaline-bearing sandstone (Zeegers and Lecomte, 1992).

The sillimanite-cordierite gneiss could represent the base of the lateritic profile on the rhyodacitic precursor to the biotite gneisses that host the borosilicate occurrence at Bok se Puts (Fig. 10). Its spidergram (Fig. 11) is not unlike that of typical granitic rocks, with low $\mathrm{Sr}, \mathrm{P}$, and $\mathrm{Ti}$, relative to LREE and $\mathrm{Y}$; however $\mathrm{Na}$ is relatively low and its aluminium saturation index, $\mathrm{ASI}=\mathrm{Al} /(2 \mathrm{Ca}+\mathrm{K}+\mathrm{Na})=2.6$, is much higher than the ASI of fresh granitic rocks.

Figure 12 compares compositions of the Bok se Puts borosilicate and oxide rocks with an average for all bauxites (Bronevoy et al., 1984, 1985); this average gives an overall orientation for lateritic bauxites as these constitute $88 \%$ of all bauxites in terms of weight (Bárdossy and Aleva, 1990). For a sizable number of constituents, notably, $\mathrm{Al}, \mathrm{Ti}, \mathrm{Fe}$, $\mathrm{Sc}, \mathrm{V}, \mathrm{Cr}, \mathrm{Y}, \mathrm{Nb}, \mathrm{Ba}$ and $\mathrm{Th}$, there is a remarkable correspondence between the compositions of the Bok se Puts borosilicate and oxide rocks on the one hand and average bauxite on the other. The most marked discrepancies that are not obviously related to metamorphic or anatectic processes (see below) are the high contents of $\mathrm{Mg}, \mathrm{Mn}, \mathrm{Co}, \mathrm{Ni}$, $\mathrm{Zn}, \mathrm{Zr}$ and La relative to their average content in bauxite. However, anomalously high contents of these elements may not be unique to Bok se Puts. $\mathrm{Co}, \mathrm{Ni}, \mathrm{Zn}, \mathrm{Zr}$ and $\mathrm{La}$ are among the elements that Bol et al. (1989) found enriched in $\mathrm{Fe}-\mathrm{Al}$ granofels consisting largely of plagioclase, spinel sensu lato, opaque oxide, cordierite and sillimanite from Rogaland, Norway, enrichments they attributed to pre-metamorphic lateritization of a basaltic protolith. In the case of Bok se Puts, the elevated contents of $\mathrm{Zr}$ and $\mathrm{La}$ could be due to resistant minerals (zircon, monazite) inherited from the parent rock, a phenomenon observed in bauxite (Bárdossy and Aleva, 1990; Moore and Waters, 1990). Enrichments of $\mathrm{Mn}$ and $\mathrm{Ni}$ have been reported in a few lateritic bauxite deposits, e.g. lithiophorite, $(\mathrm{Al}, \mathrm{Li})\left(\mathrm{Mn}^{4+}, \mathrm{Mn}^{3+}\right) \mathrm{O}_{2}(\mathrm{OH})_{2}$ 


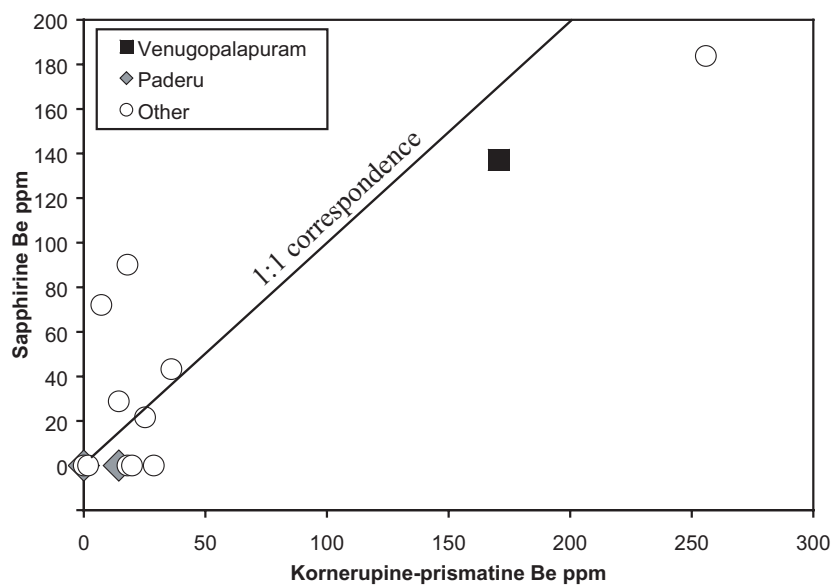

FIG. 9. Beryllium contents of associated sapphirine and kornerupine-prismatine. Sources: Grew et al. (1990a, 1998a) and references cited therein for other and Paderu data; this study for Venugopalapuram data.

(Bárdossy and Aleva, 1990). If the precursors to the borosilicate and oxide rocks contained admixed kaolinite (as does the Amazon region latosol cited above) or montmorillonite, enrich- ment in $\mathrm{Li}, \mathrm{Co}, \mathrm{Ni}$ and $\mathrm{Zn}$ is possible (Zeegers and Lecomte, 1992).

The relatively high $\mathrm{MgO}$ content is harder to explain. Bol et al. (1989) suggested that the

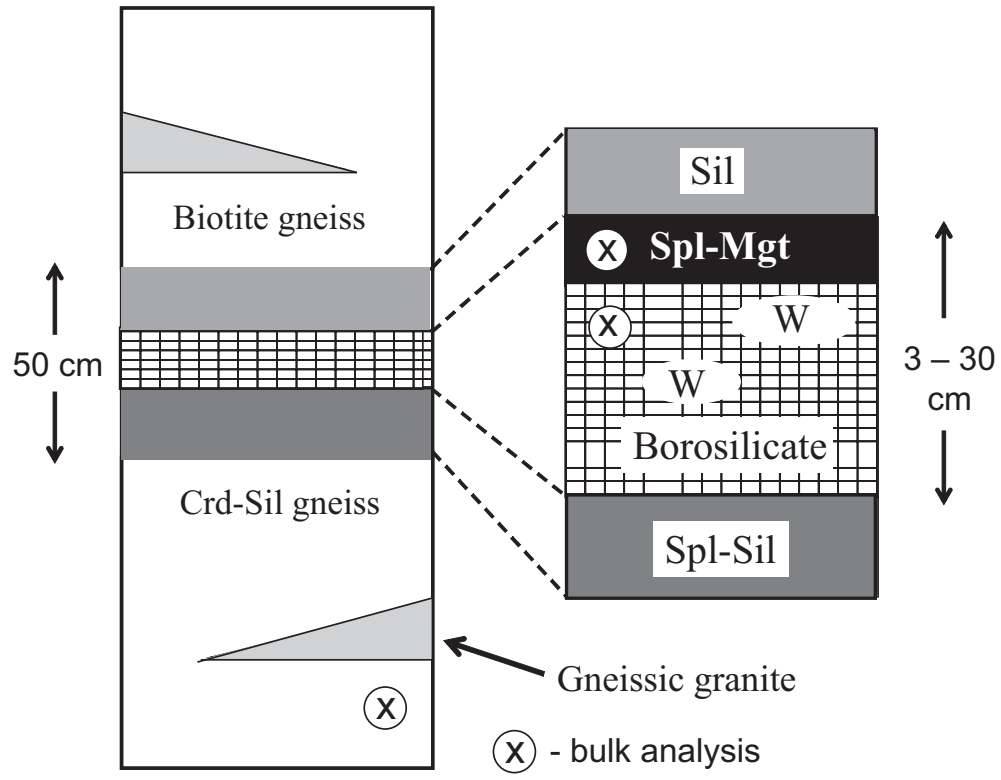

FIG. 10. Schematic cross sections of the borosilicate and associated oxide- and sillimanite-rich rocks at Bok se Puts, Namaqualand Metamorphic Complex, South Africa. The Spl-Mgt rock is hercynite-ilmenite-magnetite-sillimanite with minor amounts of biotite/phlogopite and zircon. The Sil and Sil-Spl rocks have the same constituents, but sillimanite and sillimanite + hercynite are dominant, respectively. The Crd-Sil gneiss is quartz-microperthitecordierite-plagioclase-biotite-sillimanite-hercynite with lesser ilmenite-magnetite, apatite, zircon and possibly monazite. The ovals labelled $\mathrm{W}$ indicate werdingite-bearing lenticular pockets in the borosilicate rock. Mineral abbreviations: $\mathrm{Crd}$ - cordierite, Mgt - magnetite, Sil - sillimanite, $\mathrm{Spl}$ - spinel sensu lato. 


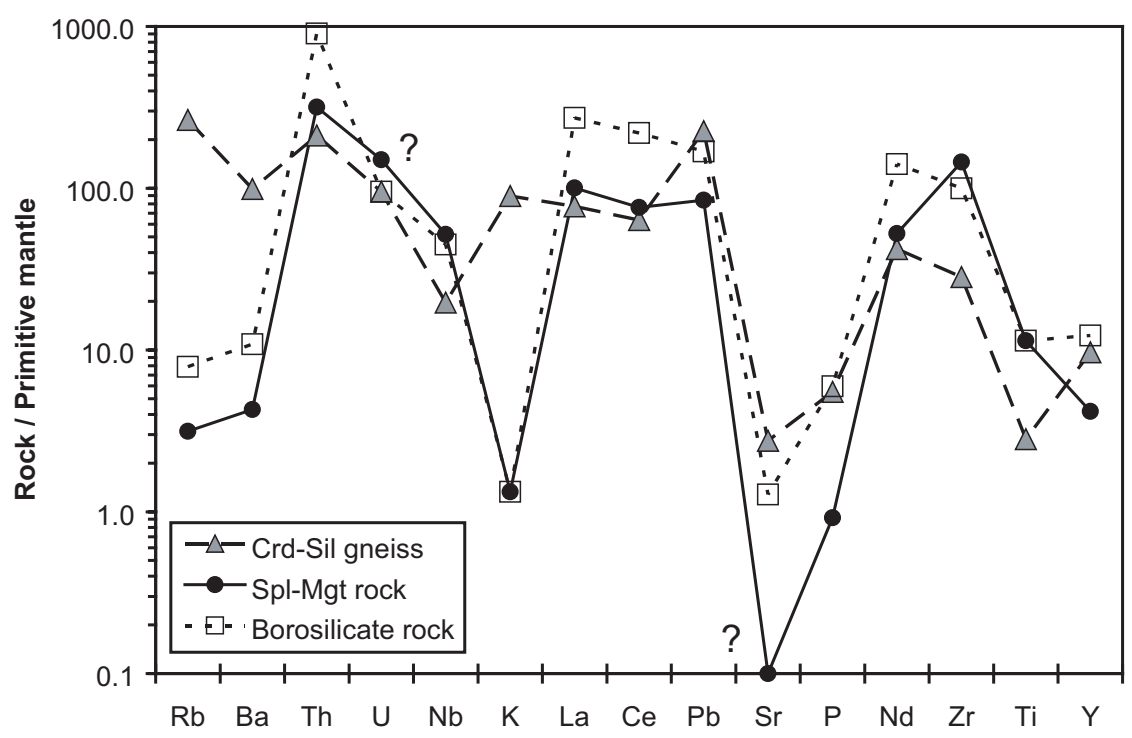

FIg. 11. Spidergram for three rocks from Bok se Puts, Namaqualand Metamorphic Complex, South Africa (Table 5) normalized to primitive mantle (Sun and McDonough 1989). The question mark (?) indicates that the plotted ratio is the maximum possible because the element is below detection ( $\mathrm{Sr}$ and $\mathrm{U}$ in Spl-Mgt rock).

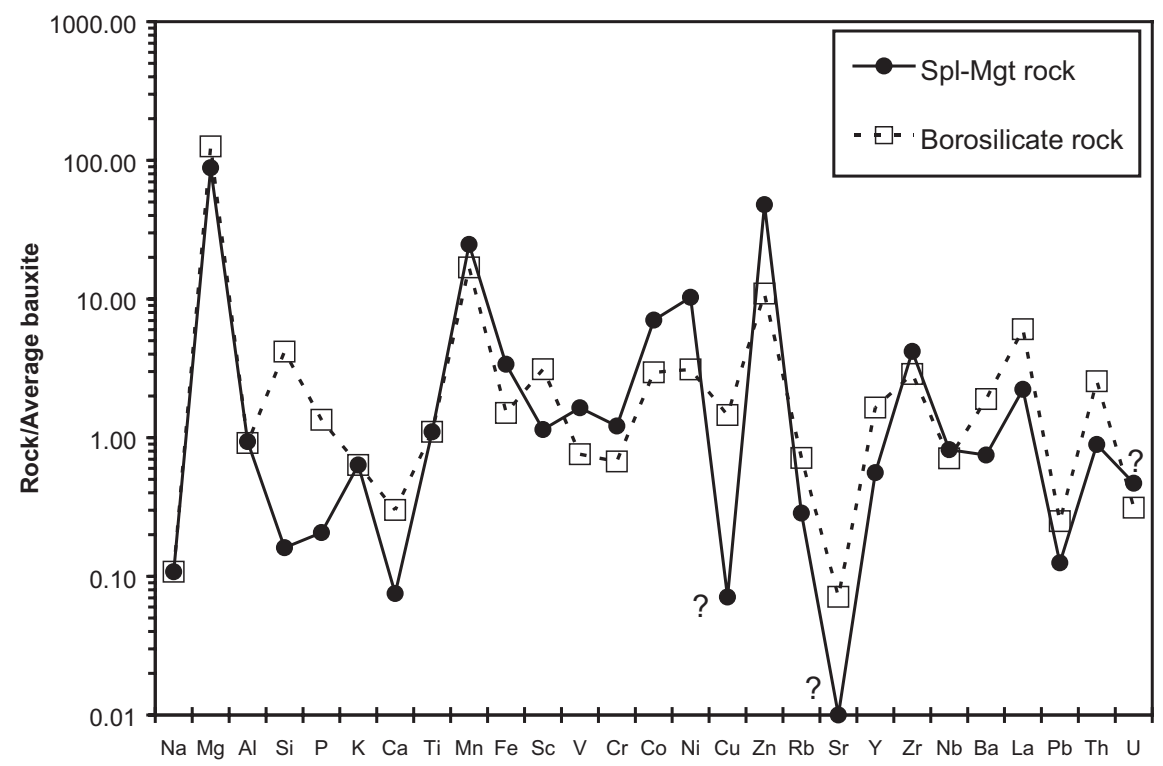

FIG. 12. Spidergram for two rocks from Bok se Puts, Namaqualand Metamorphic Complex, South Africa (Table 5) normalized to average bauxite (Bronevoy et al. 1984, 1985). The question mark (?) indicates that the plotted ratio is the maximum possible because the element is below detection $(\mathrm{Cu}, \mathrm{Sr}, \mathrm{U}$ in $\mathrm{Spl}-\mathrm{Mgt}$ rock). 
relatively high but variable $\mathrm{MgO}$ content in the Rogaland Fe-Al granofels resulted from metasomatic contamination from nearby dolomite marble. In the absence of marble at Bok se Puts, dravite might have contributed some of the $\mathrm{Mg}$ to the precursors of the borosilicate and spinelmagnetite rocks, but in the latter case, B was entirely lost during metamorphism. Clays are conceivably an $\mathrm{Mg}$ source, e.g. chlorite is a very rare constituent of bauxite (Bárdossy and Aleva, 1990). We cannot exclude the possibility that the laterite had a mafic component that was not preserved in its unweathered form. This could also account for the high $\mathrm{V}, \mathrm{Cr}, \mathrm{Co}, \mathrm{Zn}$ and $\mathrm{Ni}$ contents.

Gallium, like $\mathrm{Al}, \mathrm{Cr}$ and $\mathrm{V}$, is generally present in elevated amounts in bauxite (Bárdossy and Aleva, 1990). The presence of significant $\mathrm{Ga}$ in ferrohögbomite- $2 N 2 S$ in the Venugopalapuram magnetite-rich rock suggests some bulk $\mathrm{Ga}$ enrichment, which lends support to its having a lateritic bauxite precursor.

Metamorphism and anatexis also had an effect, albeit subordinate, on the resulting compositions of the $\mathrm{Al}-\mathrm{Fe} \pm \mathrm{B}$ rocks, most likely, through dehydration melting of a tourmaline-bearing assemblage. In general, tourmaline dominated by the dravite component is stable up through the upper amphibolite facies of metamorphism, but has been found in granulite-facies rocks (e.g. Henry and Dutrow, 2002). Tourmaline did not survive the temperatures of $\geqslant 800^{\circ} \mathrm{C}$ estimated for the localities listed in Table 4 except Urungwe, where secondary tourmaline developed as temperature dropped below $700-750^{\circ} \mathrm{C}$ (Grew et al., 1997). Experimental studies of the stability of dravitic tourmaline, reviewed in Werding and Schreyer (2002), indicate that at high temperature it undergoes incongruent melting reactions, leaving aluminous and B-bearing phases in the residue, notably prismatine from 900 to $1000^{\circ} \mathrm{C}$ and from 5 to $25 \mathrm{kbar}$. Crucially, it appears that the entire Na content of tourmaline enters the melt and vapour phases. Therefore, the following reaction relationship is a possible explanation for tourmaline breakdown at localities listed in Table 4:

Dravitic tourmaline \pm biotite $\rightarrow$ prismatine \pm grandidierite \pm werdingite \pm sapphirine + melt dominated by Na-plagioclase and containing $\mathrm{B}_{2} \mathrm{O}_{3}$ and $\mathrm{H}_{2} \mathrm{O}$

A melt of this composition might be sufficiently mobile not to leave typical leucosomes in the source rock, although it would have had potential to interact with neighbouring rocks or form pegmatitic segregations. Removal of this melt could explain depletion of $\mathrm{Na}, \mathrm{Ca}$ and $\mathrm{Sr}$ (also $\mathrm{Pb}$ and $\mathrm{U}$ ?) in the Bok se Puts borosilicate and oxide rocks relative to average bauxite, whereas $\mathrm{K}, \mathrm{Rb}$ and $\mathrm{Ba}$ were not greatly depleted (Fig. 12). The Mg-enriched lateritic precursor created an environment conducive to the formation of prismatine and other borosilicates and thereby allowed significant retention of $\mathrm{B}$ in the restitic assemblage; prismatine would also be a suitable host for retaining $\mathrm{Li}$.

\section{Acknowledgements}

Financial support to ESG and MGY was provided from US National Science Foundation grants OPP-9813569 and OPP-0087235 to the University of Maine. Edwin Gnos is thanked for his assistance with electron microprobe analyses at the University of Bern. We thank an anonymous reviewer for constructive comments of an earlier version of the paper.

\section{References}

Anderson, S.M. (1975) Grandidierite and kornerupine: two boron-bearing minerals new to Rhodesia. Annals of the Rhodesian Geological Survey, 1, 49-59.

Angélica, R.S., da Costa, M.L. and Pöllman H. (1996) Gold, wolframite, tourmaline-bearing lateritized gossans in the Amazon region, Brazil. Journal of Geochemical Exploration, 57, 201-215.

Armbruster, T. (2002) Revised nomenclature of högbomite, nigerite, and taaffeite minerals. European Journal of Mineralogy, 14, 389-395.

Barbier, J., Grew, E.S., Hålenius, E., Hålenius, U. and Yates, M.G. (2002) The role of Fe and cation order in the crystal chemistry of surinamite, $\left(\mathrm{Mg}, \mathrm{Fe}^{2+}\right)_{3}\left(\mathrm{Al}, \mathrm{Fe}^{3+}\right)_{3} \mathrm{O}\left[\mathrm{AlBeSi}_{3} \mathrm{O}_{15}\right]$ : A crystal structure, Mössbauer spectroscopic, and optical spectroscopic study. American Mineralogist, 87, 501-513.

Bárdossy, G. and Aleva, G.J.J. (1990) Lateritic Bauxites. Developments in Economic Geology, 27. Elsevier, Amsterdam and Akadémiai Kiadó és Nyomda Vállalat, Budapest.

Bhattacharya, S. and Kar, R. (2002) High-temperature dehydration melting and decompressive P-T path in a granulite complex from the Eastern Ghats, India. Contributions to Mineralogy and Petrology, 143, 175-191.

Bol, L.C.G.M., Maijer, C. and Jansen, J.B.H. (1989) Premetamorphic lateritisation in Proterozoic metabasites of Rogaland, SW Norway. Contributions to 
Mineralogy and Petrology, 103, 306-316.

Bronevoy, V.A., Zil'bermints, A.V., Lipin, V.M. and Tenyakov, V.A. (1984) Distribution (average contents) of chemical elements in bauxites of the world. Doklady Akademii Nauk SSSR, 276, 183-186 (in Russian).

Bronevoy, V.A., Zil'bermints, A.V. and Tenyakov, V.A. (1985) Average chemical composition of bauxites and its change over time. Geochemistry International, 22(7), 77-90

Cooper, M.A. (1997) The crystal chemistry of kornerupine. M.Sc. thesis, University of Manitoba, Winnipeg, Canada.

Dingwell, D.B., Pichavant, M. and Holtz, F. (2002) Experimental studies of boron in granitic melts. Pp. 331-385 in: Boron: Mineralogy, Petrology, and Geochemistry (E.S. Grew and L.M. Anovitz, editors). Reviews in Mineralogy, 33 ( $2^{\text {nd }}$ printing with corrections and additions). Mineralogical Society of America, Washington, D.C.

Dyar, M.D., Wiedenbeck, M., Robertson, D., Cross, L.R., Delaney, J.S., Ferguson, K., Francis, C.A., Grew, E.S., Guidotti, C.V., Hervig, R.L., Hughes, J.M., Husler, J., Leeman, W., McGuire, A.V., Rhede, D., Rothe, H., Paul, R.L., Richards, I. and Yates, M. (2001) Reference minerals for the microanalysis of light elements. Geostandards Newsletter, 25, $441-463$.

Grew, E.S. (1982) Sapphirine, kornerupine, and sillimanite + orthopyroxene in the charnockitic region of South India. Journal of the Geological Society of India, 23, 469-505.

Grew, E.S. (2002a) Borosilicates (exclusive of tourmaline) and boron in rock-forming minerals in metamorphic environments. Pp. 387-502 in: Boron: Mineralogy, Petrology, and Geochemistry (E.S. Grew and L.M. Anovitz, editors). Reviews in Mineralogy, 33 ( $2^{\text {nd }}$ printing with corrections and additions). Mineralogical Society of America, Washington, D.C.

Grew, E.S. (2002b) Beryllium in metamorphic environments (emphasis on aluminous compositions). Pp. 487-549 in: Beryllium: Mineralogy, Petrology, and Geochemistry (E.S. Grew, editor). Reviews in Mineralogy and Geochemistry, 50. Mineralogical Society of America, Washington, D.C.

Grew, E.S. and Hinthorne, J.R. (1983) Boron in sillimanite. Science, 221, 547-549.

Grew, E.S., Chernosky, J.V., Werding, G., Abraham, K., Marquez, N. and Hinthorne, J.R. (1990a) Chemistry of kornerupine and associated minerals, a wet chemical, ion microprobe, and X-ray study emphasizing $\mathrm{Li}, \mathrm{Be}, \mathrm{B}$ and $\mathrm{F}$ contents. Journal of Petrology, 31, 1025-1070.

Grew, E.S., Hiroi, Y. and Shiraishi, K. (1990b) Högbomite from the Prince Olav Coast, East
Antarctica: An example of oxidation-exsolution of a complex magnetite solid solution? American Mineralogist, 75, 589-600.

Grew, E.S., Yates, M.G., Konilov, A.N. and Marquez, N. (1992) Kornerupine from the Archaean Kola Series at Sholt-Yavr, Kola Peninsula, Russia. Mineralogical Magazine, 56, 247-251.

Grew, E.S., Cooper, M.A. and Hawthorne, F.C. (1996) Prismatine: revalidation for boron-rich compositions in the kornerupine group. Mineralogical Magazine, 60, 483-491.

Grew, E.S., Yates, M.G., Shearer, C.K. and Wiedenbeck, M. (1997) Werdingite from the Urungwe District, Zimbabwe. Mineralogical Magazine, 61, 713-718.

Grew, E.S., Pertsev, N.N., Vrána, S., Yates, M.G., Shearer, C.K. and Wiedenbeck, M. (1998a) Kornerupine parageneses in whiteschists and other magnesian rocks: is kornerupine + talc a highpressure assemblage equivalent to tourmaline + orthoamphibole? Contributions to Mineralogy and Petrology, 131, 22-38.

Grew, E.S., Yates, M.G., Huijsmans, J.P.P., McGee, J.J., Shearer, C.K., Wiedenbeck, M. and Rouse, R.C. (1998b) Werdingite, a borosilicate new to granitic pegmatites. The Canadian Mineralogist, 36, 399-414.

Grew, E.S., Redhammer, G.J., Amthauer, G., Cooper, M.A., Hawthorne, F.C. and Schmetzer, K. (1999) Iron in kornerupine: $\mathrm{A}^{57} \mathrm{Fe}$ Mössbauer spectroscopic study and comparison with single-crystal structure refinement. American Mineralogist, 84, 536-549.

Grew, E.S., Yates, M.G., Barbier, J., Shearer, C.K., Sheraton, J.W., Shiraishi, K. and Motoyoshi, Y. (2000) Granulite-facies beryllium pegmatites in the Napier Complex in Khmara and Amundsen Bays, western Enderby Land, East Antarctica. Polar Geoscience, 13, 1-40.

Grew, E.S., Rao, A.T., Raju, K.K.V.S. and Yates, M.G. (2001) Re-examination of quartz-sillimanite-hypersthene-cordierite gneisses from the Vijayanagaram district: Does surinamite occur in the Eastern Ghats Belt? Current Science, 81, 1353-1358.

Hejny, C. and Armbruster, T. (2002) Polysomatism in högbomite: The crystal structures of $10 \mathrm{~T}, 12 \mathrm{H}, 14 \mathrm{~T}$, and $24 R$ polysomes. American Mineralogist, 87, $277-292$.

Hejny, C., Gnos, E., Grobéty, B. and Armbruster, T. (2002) Crystal chemistry of the polysome ferrohögbomite- $2 N 2 S$, a long-known but newly defined mineral species. European Journal of Mineralogy, 14, 957-967.

Henry, D.J. and Dutrow, B.L. (2002) Metamorphic tourmaline and its petrologic applications. Pp. 503-557 in: Boron: Mineralogy, Petrology, and Geochemistry (E.S. Grew and L.M. Anovitz, 
editors). Reviews in Mineralogy, 33 ( $2^{\text {nd }}$ printing with corrections and additions). Mineralogical Society of America, Washington, D.C.

Higgins, J.B., Ribbe, P.H. and Herd, R.K. (1979) Sapphirine 1. Crystal chemical contributions. Contributions to Mineralogy and Petrology, 68, 349-356.

Kamineni, D.C. and Rao, A.T. (1988) Sapphirinebearing quartzite from the Eastern Ghats granulite terrain, Vizianagaram, India. Journal of Geology, 96, 209-220.

Lal, R.K., Ackermand, D. and Upadhyay, H. (1987) P$T-X$ relationships deduced from corona textures in sapphirine-spinel-quartz assemblages from Paderu, southern India. Journal of Petrology, 28, $1139-1168$.

Leeman, W.P. and Sisson, V.B. (2002) Geochemistry of boron and its implications for crustal and mantle processes. Pp. 645-708 in: Boron: Mineralogy, Petrology, and Geochemistry (E.S. Grew and L.M. Anovitz, editors). Reviews in Mineralogy, 33 ( $2^{\text {nd }}$ printing with corrections and additions). Mineralogical Society of America, Washington, D.C.

Moore, J.M. and Waters, D.J. (1990) Geochemistry and origin of cordierite-orthoamphibole/orthopyroxene-phlogopite rocks from Namaqualand, South Africa. Chemical Geology, 85, 77-100

Moore, J.M., Waters, D.J. and Niven, M.L. (1990) Werdingite, a new borosilicate mineral from the granulite facies of the western Namaqualand metamorphic complex, South Africa. American Mineralogist, 75, 415-420.

Munyanyiwa, H. and Maaskant, P. (1998) Metamorphism of the Palaeoproterozoic Magondi mobile belt north of Karoi, Zimbabwe. Journal of African Earth Sciences, 27, 223-240.

Munyanyiwa, H., Touret, J.L.R. and Jelsma, H.A. (1993) Thermobarometry and fluid evolution of enderbites within the Magondi mobile belt, northern Zimbabwe. Lithos, 29, 163-176.

Nanda, J.K., Natarajan, V., Purushottam, A. and Prabhavathi, R. (1983) Kornerupine from the Kondapalli area, Andhra Pradesh, India. Neues Jahrbuch für Mineralogie Monatshefte, 103-109.

Niven, M.L., Waters, D.J. and Moore, J.M. (1991) The crystal structure of werdingite, $(\mathrm{Mg}, \mathrm{Fe})_{2} \mathrm{Al}_{12}(\mathrm{Al}, \mathrm{Fe})_{2}$ $\mathrm{Si}_{4}(\mathrm{~B}, \mathrm{Al})_{4} \mathrm{O}_{37}$, and its relationship to sillimanite, mullite, and grandidierite. American Mineralogist, 76, 246-256.

Nixon, P.H., Reedman, A.J. and Burns, L.K. (1973) Sapphirine-bearing granulites from Labwor, Uganda. Mineralogical Magazine, 39, 420-428.

Nixon, P.H., Grew, E.S. and Condliffe, E. (1984) Kornerupine in a sapphirine-spinel granulite from Labwor Hills, Uganda. Mineralogical Magazine, 48, $550-552$.
Norrish, K. and Hutton, J.T. (1969) An accurate X-ray spectrographic method for the analysis of a wide range of geological samples. Geochimica et Cosmochimica Acta, 33, 431-453.

$\mathrm{Pal}$, S. and Bose, S. (1997) Mineral reactions and geothermobarometry in a suite of granulite facies rocks from Paderu, Eastern Ghats granulite belt: A reappraisal of the P-T trajectory. Proceedings of the Indian Academy of Sciences (Earth and Planetary Sciences), 106, 77-89.

Petersen, E.U., Essene, E.J., Peacor, D.R. and Marcotty, L.A. (1989) The occurrence of högbomite in highgrade metamorphic rocks. Contributions to Mineralogy and Petrology, 101, 350-360.

Ramesh-Kumar, P.V., Raju, K.K.V.S. and Ganga Rao, B.S. (1995) Surinamite (Be, B, Ga) from cordierite gneisses of eastern Ghat mobile belt, India. Current Science, 69, 763-767.

Rao, A.T., Divakara Rao, V., Yoshida, M. and Arima, M. (1997) Whole rock and mineral chemistry of aluminous granulites from the Eastern Ghats granulite belt, Andhra Pradesh. Journal of the Geological Society of India, 50, 559-570.

Sandiford, M., Neall, F.B. and Powell, R. (1987) Metamorphic evolution of aluminous granulites from Labwor Hills, Uganda. Contributions to Mineralogy and Petrology, 95, 217-225.

Sun, S.-S. and McDonough, W.F. (1989) Chemical and isotopic systematics of oceanic basalts: implications for mantle composition and processes. Pp. 313-345 in: Magmatism in the Ocean Basins (A.D. Saunders and M.J. Norry, editors). Special Publication 42. Geological Society, London.

Treloar, P.J. (1995) The regional setting and significance of a grandidierite-kornerupine-tourmaline assemblage from granulite facies rocks of northern Zimbabwe. Metamorphic Studies Group of the Mineralogical Society of Great Britain and Ireland and the Geological Society of London, Research in Progress and Annual General Meeting, Programme and Abstracts.

Treloar, P.J. and Kramers, J. D. (1989) Metamorphism and geochronology of granulites and migmatitic granulites from the Magondi Mobile Belt, Zimbabwe. Precambrian Research, 45, 277-289.

Werding, G. and Schreyer, W. (1992) Synthesis and stability of werdingite, a new phase in the system $\mathrm{MgO}-\mathrm{Al}_{2} \mathrm{O}_{3}-\mathrm{B}_{2} \mathrm{O}_{3}-\mathrm{SiO}_{2}$ (MABS), and another new phase in the ABS-system. European Journal of Mineralogy, 4, 193-207.

Werding, G. and Schreyer, W. (2002) Experimental studies on borosilicates and selected borates. Pp. 117-163 in: Boron: Mineralogy, Petrology, and Geochemistry (E.S. Grew and L.M. Anovitz, editors). Reviews in Mineralogy, 33 ( $2^{\text {nd }}$ printing with corrections and additions). Mineralogical 


\section{E. S. GREWETAL.}

Society of America, Washington, D.C.

Zeegers, H. and Lecomte, P. (1992) Seasonally humid tropical terrains (savannas). Pp. 203-240 in: Handbook of Exploration Geochemistry, volume 4, Regolith Exploration Geochemistry in Tropical and
Subtropical Terrains (C.R.M. Butt and H. Zeegers, editors). Elsevier, Amsterdam.

[Manuscript received 11 December 2002:

revised 29 July 2003] 